\title{
Stephen Hales, DD, FRS*
}

\author{
A E CLARK-KENNEDY
}

British Medical fournal, 1977, 2, 1656-1658

Stephen Hales was born on 17 September 1677 and came up to the college in 1696. His tutor was the Reverend Robert Moss, DD, a latitudinarian in religion; his education wide-classics, mathematics, divinity, philosophy. In 1703 he took his MA degree, was ordained deacon, and elected a fellow.

A year later a strange young man matriculated at Corpus. $\mathrm{He}$ was certainly young. "We had an old cat, a great favourite of my father's," writes William Stukeley, "and by mother's consent I did rid her of the infirmities of age and made a handsome skeleton which I carried with me to Cambridge. There I turned my mind particularly to physick, and began to make inquisition into anatomy and to dissect all sorts of animals; and saw, too, many philosophical experiments performed by $\mathrm{Mr}$ Waller, professor of chemistry and parson at Grantchester, with $\mathrm{Mr}$ Stephen Hales, a fellow of the college."

"My tutor gave me a room in which to practise my chymical experiments," continues Stukeley. "Here I often prepared the pulvis fulminans and surprised the college with an explosion in the night. I also visited the apothecary's shop and exercised a little gratis practice among the poor people that depended on the college. Smith, our joiner, in gratitude promised me his body to dissect when he died which, happening when I was out of college, he expressed much concern that I could not have the benefit of his promise. Mr Rolf, too, had been declared professor of anatomy. He was also curious in the knowledge of botanics; and he and I and Mr Stephen Hales used to go frequently asimpling over the Gogmagog hills and Cherry Hinton moors, armed with candle boxes and Ray's Catalogus in our pockets."

Hales and Stukeley also went to the lectures that Vigani gave in Queens' and to his chemical experiments in the "elegant chymical laboratory" that Bentley had built on the fellows' bowling green at Trinity. They also attended Roger Cotes's lectures in astronomy-Hales constructed an orrery; Stukeley drew a picture of it-and used the telescope which had been installed by Newton over Great Gate.

Stukeley went down in 1708 to practise as a doctor in Lincolnshire. Hales, having been ordained priest and taken his BD, was appointed to a country living. So the partnership broke up. But Stukeley's youthful enthusiasm had fired in the older man a serious interest in biology and, "in Teddington's serene retreat for philosophic studies meet," Hales embarked on those extraordinary experiments that led him to become the greatest physiologist since Harvey.

No one had yet measured the blood pressure. Hales, his eyes set on how the body works (rather than on how it is made), succeeded in measuring it both in the arteries and in the veins; and made many other observations which have added to our knowledge of the mechanics of the circulation. He estimated, for instance, the output of the heart per minute, and demon-

*In this address, which was given in Corpus Christi College Chapel, Cambridge, at the Commemoration of Benefactors on 3 December 1976, many of the quotations had to be abbreviated for the sake of brevity or slightly modified for the sake of clarity. All are to be found, accurate and in full, in Dr Clark-Kennedy's biography, Stephen Hales, DD, FRS, Physiologist and Botanist, Cambridge University Press, 1929. This has long since been out of print but was reproduced photographically, both in paper and hardback in 1965 by the Gregg Press, New Jersey, USA.

Corpus Christi College, Cambridge CB2 1 RH

A E CLARK-KENNEDY, MD, FRCP, fellow

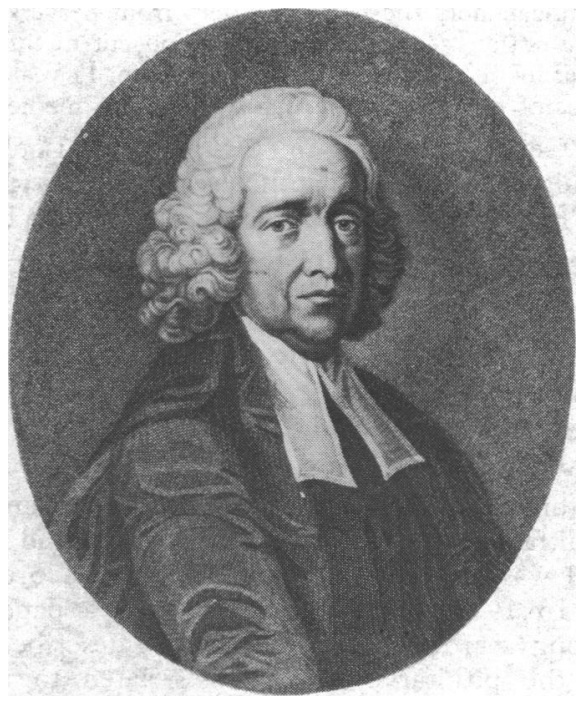

The Reverend Dr Stephen Hales (from a print in the Library of the Royal College of Physicians of London).

strated that the circulation rate of mammals is more or less inversely proportional to their size.

\section{Comparative physiologist}

This classic work remained unpublished for nearly 20 years. For he now became absorbed in botanical physiology, his first book, Vegetable Statics, opening with an account of the quantity of moisture "imbibed and perspired" by plants. Thence he was able to calculate the velocity of the sap, just as he had calculated that of the blood. But how did the sap get to the top of the tree? Transpiration from the leaves kept it going. Clearly they had a function not realised before. But what made the sap rise before the leaves came out ? Capillarity alone could not account for that.

To answer this question, he cut off a vine flush with the ground in late March and connected the cut stem with a vertical glass tube. The sap rose 43 feet in it. He had discovered and measured root pressure. "This force," he wrote, "is near five times greater than the force of the blood in the crural artery of a horse, seven times greater than in that of a dog, and eight times greater than in that of a fallow doe, which different forces I found by fixing glass tubes in these arteries, in which the blood of a horse rose eight feet, that of a dog six feet, and that of a fallow doe five feet seven inches." In 1718 he was elected a Fellow of the Royal Society and a few years later awarded the Copley Medal.

Although a doctor of divinity (of the University of Oxford) he was no theologian. Rather, he was one of the latitudinarian divines of those days who paid little attention to the differences of doctrine and ceremony which divided high churchmen from the dissenters. Moral dissertations, based on the teaching of the gospels, alternated in his sermons with pronouncements on the wisdom of God, supported by arguments from nature.

"The study of it," he wrote, "will ever yield us fresh entertainment, and we have every reason to bless God for the abilities he has given us, and the strong desire he has implanted in our minds, to reach into his works, in which the further we go, the more we see the signatures of his wisdom, because in everything we find a wise design. And the further researches we make, the 


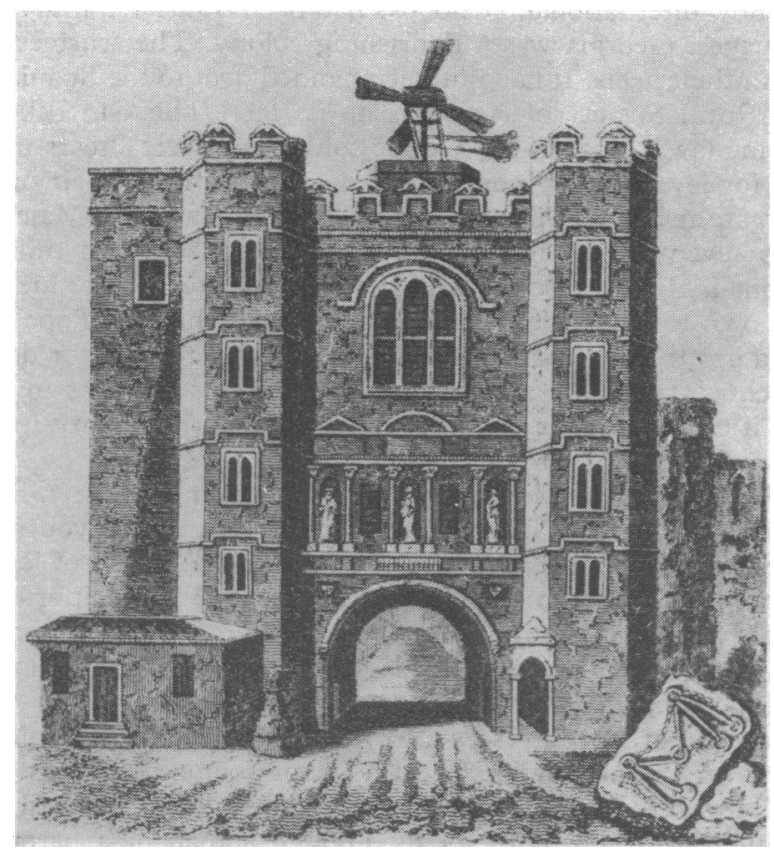

Newgate Prison in 1752 showing Dr Hales's windmill ventilator.

more harmony we find; and the stronger convictions they breed in us of the power of the divine architect who has made all things to concur in carrying on, by innumerable combinations of matter, such as circulation of cause and effect as was necessary to the great ends of nature." No one had begun to think in terms of evolution yet.

His personality and his sermons appealed to his parishioners. It became necessary to enlarge the church. $\mathrm{He}$ added another aisle. He built a new tower because they could not hear the bells. He engineered a water supply for the village. All this is meticulously recorded in the parish register which also contains many quaint entries in his own hand. "John Rolt, murdered fighting for the maypole." "James Parson, who had oft eat a shoulder of mutton and a peck of hasty pudding at a time which caused his death, buried." "Ordered that the stocks be put into repair." His hold over his parishioners, too, was strong. Offenders were required to do public penance, standing in white in church, for immorality.

\section{Humanitarian ideals}

At the age of 43 he married Mary Newce, the daughter of the rector of Much Hadham. But she died a year later, probably in childbirth, leaving him to live on at Teddington alone, save for yearly visits to Farringdon in Hampshire, of which he had been appointed rector (these were the days of holding livings in plurality), and where he installed Gilbert White, later of Selborne fame, to be his curate. He refused a canonry of Windsor but accepted the appointment of clerk of the closet and chaplain to the Dowager Princess of Wales and took great interest in the royal children. It was for the future king, George III, that he "contrived an ingenious machine to expedite the preparation of syllabub."

"He was remarkable for social virtue and sweetness of temper," wrote a contemporary, "happy in himself; beneficial to others. Further, he possessed a natural simplicity of manners which the characters of other men and customs of this world could never alter; and, though he often met with unworthy objects and uncharitable offices, yet they never once lessened his unfailing disposition for doing good. Two things in his character particularly distinguished him from other men; the first was that his mind was so bent on acquiring knowledge that he was solicitous to avoid any further preferment in the church lest his attention might thereby be diverted from his useful occupations. The other was no less singular; he could look even upon evil men, and those who did him unkind offices, without emotion or indignation; not from want of discernment or sensibility; but because he used to consider them only like those experiments which, upon trial, he found could never be applied to any useful purpose, and which he therefore calmly and dispassionately laid aside."

He repeated John Hunter's experiments on the growth of bone, and studied that of plants. He observed reflex action in spinal frogs long before Robert Whytt described it in 1757. He embarked on the unsolved problems of combustion and respiration. For oxygen had not been discovered and Stahl's phlogiston theory held the field. Ignoring Stahl, he came tantalisingly near the truth. If Mayow can be said to have virtually discovered oxygen, Hales virtually discovered carbon dioxide. Only when he touched on physick (with its quaint ideas in those days) did his judgment fail. He was party to Mrs Joanna Stephens being awarded $£ 5000$ of taxpayers' money by Act of Parliament for her medical cure for the stone. This, on being divulged by the lady, proved to consist of "snail shells well calcined and swines cress burnt to a blackness."

As the years went by, although his originality of mind began to decline, its vigour never failed, and now we find him turning away from pure science in the direction of the needs of men. He was a co-founder of the Royal Society of Arts and a trustee of the Colony of Georgia started by General Oglethorpe as an asylum for debtors on release from prison in this country. These, too, were the days of Hogarth's Gin Lane; “drunk for a penny, dead drunk for twopence." He organised a campaign, writing pamphlet after pamphlet, urging the Government into action in the face of this fast growing social evil.

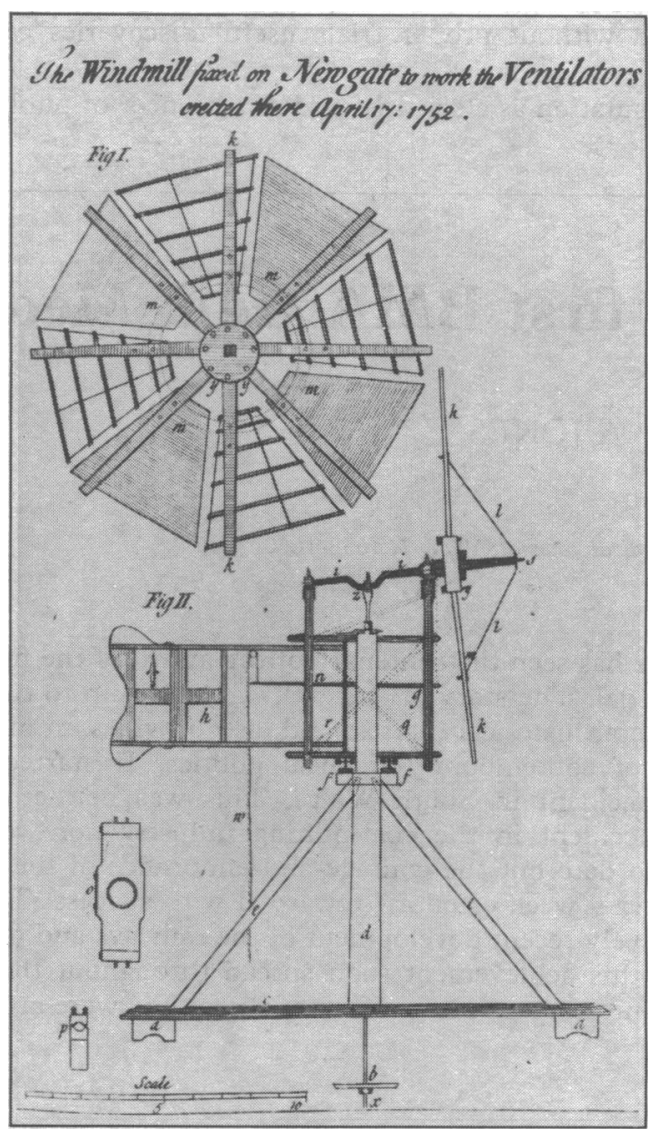

Hales ventilator for Newgate Prison (from a copy of the Gentleman's magazine (1752) in the Library of the Royal College of Physicians of London). 


\section{Pioneer in public health}

Gaol distemper, believed then to be due to contaminated air, was also taking its toll of human life. It was natural, therefore, that Hales, as his interests became more and more humanitarian, should switch from the academic study of the respiration of animals to the practical problem of the ventilation of buildings. He devised machines, driven by windpower, which sucked the stale air out to let fresh air get in. His method was cumbersome. But such was the force of his personality that he got his windmills erected over St George's Hospital and over many prisons, notably the notorious Newgate and the Savoy; his ventilating systems installed in many of His Majesty's ships, even in ships carrying slaves, battened down between decks, in the long voyage across the Atlantic. When the Seven Years' War broke out, he corresponded with the enemy and strove to get them installed wherever British were confined in France.

His ventilators must have reduced the incidence of airborne disease, notably that of tuberculosis, but it is unlikely that they affected the mortality of gaol fever. Typhus is conveyed from man to man, not by air, but by body lice.

Having got his ventilators adopted-and it had been uphill work indeed-he could get back to his first love, and at 80 we see him at his last experiment. It concerned the respiration of fish. "June 7. The wind SW. Thermometer $58^{\circ} .13$ gudgeon were put in 2 gallons of pond water in Pail $A$ and a like number in Pail B." Pail A was "ventilated" with air. Pail B was not "ventilated." All the fish in the latter died, showing that fish were dependent on air dissolved in water. But I quote this experiment to point the unquenchable experimental spirit in the man, exemplified, too, by quaint ideas he held about salt water. "If the trial were made in 20 tents," he wrote, "to wet the soldiers' bodies with it in cold weather (he was worrying about the health of our service personnel), it would probably give some light unto the matter"-and then a little wearily"but I know by very much experience that the indolence in mankind is too great to attempt useful discoveries by proper trials and without proper trials useful discoveries cannot be made."

His reputation as a scientist and as a pioneer of public health was now international. His books had been translated into many languages. Georgia was a flourishing colony. The trustees had dug in their heels. It had not been handed over to the Spaniards. The Royal Society of Arts was on its feet. The Gin Bill had become law. (That night, we are told, there were "tears in his eyes for joy.") His windmills raced, sucking the foul air out of Newgate and the Savoy; out of St George's; out of His Majesty's ships; even out of slave ships on the high seas and military prisons in France. So he could settle down to his fireside and get down to his garden-he was a friend of the poet Pope who had a grotto garden at Twickenham-calmly to wait for death, an acquaintance, we are told, "long familiarised to his mind." And it came to him quietly at Teddington in his eighty-fourth year.

"As I know you loved the good old man," wrote Gilbert White to a friend, "how can I do better than send you some anecdotes respecting him. His attention to the inside of ladies' tea-kettles that from thence he might judge the salubrity of their wells; his advising water to be showered down suspicious ones before men ventured to descend; his teaching the housewife to place an inverted egg cup at the bottom of her tarts and pies in order to preserve the juice; his directing air holes to be left in the out-walls of ground floor rooms to prevent dry rot. These are but a few among those useful pursuits on which his mind was constantly bent. Though a man of a baronet's family and of one of the best houses in Kent, yet was his humility so prevalent that he did not disdain the lowest offices, provided they tended to the good of his fellow men. The last act of benevolence on which I saw him employed-and $I$ can somehow see him at it now-was at Farrington, the next parish to this, where I found him in the street with his paint pot before him, much busied in painting white, with his own hands, the tops of the foot-path posts, lest his neighbours might run against them in the dark."

His monument stands in Westminster Abbey. His bones lie buried under the tower which he had built himself for the old church at Teddington about which he had cared so much. "How well," wrote John Wesley in his diary-Wesley had visited him at Teddington-"how well did science and religion agree in that man of sound understanding."

\section{The first BMA Gold Medal}

\section{PHILIP A JONES}

British Medical fournal, 1977, 2, 1658-1660

This year has seen the centenary of the award of the first BMA Gold Medal. The story of the events that led up to this award is of general historical interest and also provides an interesting glimpse of contemporary medical politics. It started with a mining accident in South Wales. This was neither the first serious accident in the coal-mining industry nor was it the biggest to date but the courage and endurance of the rescuers were, after a week of effort, rewarded with success. Thanks to the relatively recent development of the railways and telegraph, news of this achievement soon spread throughout the nation, and the interest and imagination of the public were aroused.

Redditch, Worcestershire

PHILIP A JONES, MB, BS, general practitioner
The Rhondda valleys at the beginning of the nineteenth century were wild and in places impassable. For three decades the population would number only a few hundred. Then coal was discovered, and by the end of the century there would be 130000 inhabitants, all dependent for their livelihood on the several collieries that had opened up throughout the district. The Tynewydd Colliery was situated at Porth, the "door" to the two valleys.

\section{Dr Henry Naunton Davies}

The surgeon to this colliery was Dr Henry Naunton Davies. $\mathrm{He}$ had been born locally in 1827 . His father and grandfather were both doctors, and the family had at that time already given a hundred years of service to the local community. Further generations down to the present time have carried this tradition of service much further afield. ${ }^{1}$ Henry Davies went to school in Swansea and then to Guy's Hospital. He qualified in 1854 and succeeded to the practice which had been left vacant 